\title{
Addis Abäba as Place of Ecumenical Dialogue between Eastern and Oriental Orthodox Churches
}

\author{
Andrei Macar
}

\section{Introduction}

Addis Abäba has been an important place for ecumenical dialogue. It has been the forum for many discussions and ecumenical encounters not just in the last century, but to this day. Among these encounters were the meeting of the Central Committee of World Council of Churches (WCC) from $1971,{ }^{1}$ the assembly of the Christian Students Associations from $1973,{ }^{2}$ and the ninth meeting of the Joint Commission for Theological Dialogue between the Catholic Church and the Oriental Orthodox churches from $2012,{ }^{3}$ to name just a few. Beside these meetings, four others took place in Addis Abäba from 1965 to 1976, which dealt with the dialogue between Eastern Orthodox and Oriental Orthodox churches. It is not difficult to observe that most of these dialogue meetings took place around the 1970s, and therefore it is justified to ask what qualified the Ethiopian Orthodox Täwahədo Church to be the host for such events at the time.

First of all, one has to bear in mind that the Ethiopian Orthodox Church became autocephalous in 1959, just before this prolific time for ecumenical dialogue. The autocephaly was achieved mainly through the contribution of Emperor Haylä Śllase I (1930-1974), who was the leader of the Ethiopian efforts near the Coptic Church in Egypt for achieving this desideratum. His intention was to gain control over the Ethiopian Orthodox Church, which led some

1 See Emmanuel Lanne, "Le Comité central du Conseil oecuménique, Addis-Abéba, 10-21 janvier 1971," Irénikon 44, no. 1 (1971): 39-54; M.M. Thomas, "Report of the Executive Committee by the Chairman," The Ecumenical Review 23, no. 2 (1971): 89-104.

2 See "Les étudiants orthodoxes à l'Assemblée Générale de la F.U.A.C.E. à Addis-Abeba," Episkepsis 71, no. 4 (1973): 8-11.

3 For a short report on this dialogue meeting, see: "International Joint Commission for Theological Dialogue between the Catholic Church and the Oriental Orthodox Churches Report, Ninth Meeting, Addis Ababa, Ethiopia, January 17 to 21, 2012," Pontifical Council for Promoting Christian Unity, accessed 12.05.2021. URL: http://www.christianunity.va/content/unitacristian i/en/dialoghi/sezione-orientale/chiese-ortodosse-orientali/commissione-mista-internazion ale-per-il-dialogo-teologico-tra-la/rapporti/testo-in-inglese5.html. 
scholars to affirm that "freed from its dependence on the Coptic Church, it immediately came under the tutelage of the monarchy." However, the fact that the emperor supported the emancipation of the Ethiopian Orthodox Church and its openness to ecumenism should not be understood as exclusively determined by his political and diplomatic interests. It might be true that these efforts could have strengthened his internal control and made the country more visible at an international level, but one cannot say that all this was done unrelated to the emperor's attachment to Christian values in general, and to the Ethiopian Orthodox Church in particular. This attachment is clear from the Ethiopian constitution of 1955, which defined the emperor as "defender of Orthodox faith."5 Moreover, Haylä Śəllase's openness and interest in ecumenical dialogue, especially with the Eastern Orthodox church family, is shown by the fact that he supported cultivated and foresighted clerics, such as Basəlyos $\left(1883^{-1970}\right)^{6}$ and Tewoflos $(1909-1979)^{7}$ to become leaders of the втос. In addition, he had for a while Paul Verghese as personal counsellor, ${ }^{8}$ one of

4 Stéphane Ancel and Éloi Ficquet, "The Ethiopian Orthodox Tewahedo Church (вотC) and the Challenges of Modernity," in Understanding Contemporary Ethiopia. Monarchy, Revolution and the Legacy of Meles Zenawi, ed. Gérard Prunier and Éloi Ficquet (London: Hurst, 2015), 74.

5 Karl Pinggéra, "Die Äthiopisch-Orthodoxe Kirche und die Eritreisch-Orthodoxe Kirche," in Die altorientalischen Kirchen. Glaube und Geschichte, ed. Christian Lange and Karl Pinggéra (Darmstadt: Wissenschaftliche Buchgesellschaft, 2010), 49.

6 Abunä Basəlyos was the first Ethiopian metropolitan of the Ethiopian Orthodox Church in history (since 1951), and he also became its first patriarch in June 1956. Before this, he was superior of the Ethiopian monastery in Jerusalem. He joined Haylä Śllase in Sudan during the Italian occupation of Ethiopia, and after the defeat of the Italians was de facto the leader of the church and the most important advisor of the emperor in religious matters. See Bairu Tafla, "Basəlyos," in EAe 1 (2003): 495-496.

7 Abunä Tewoflos was the second patriarch of the Ethiopian Orthodox Church. He was elected on 9 May 1971 (after the death of Patriarch Basəlyos in October 1970, he was a locum tenens of the patriarchal throne up to the official election). He is considered a reformer of the church, because he modernized the administration, the theological education system and he introduced the first modern church constitution. As a delegate of the Ethiopian Orthodox Church, Abunä Tewoflos attended several ecumenical meetings of the wCC: in 1948 (Amsterdam), 1955 (England), 1971 (Ethiopia), and 1975 (Kenya). Furthermore, he encouraged the dialogue with the Roman Catholic Church and the Eastern Orthodox churches. After the communist revolution in 1974, Abunä Tewoflos was arrested, because of his opposition to the Derg Regime. He was executed in 1979. See Dirshaye Menberu, "Tewoflos," in Dictionary of African Christian Biography, ed. Jonathan Bonk et al., accessed 29.01.2019. URL: https://acb.org/stories/ ethiopia/tewoflos2/; Mersha Alehegne, "Tewoflos," in EAe 4 (2010): 938-939.

8 Lukas Pieper, "Paulos Mar Gregorios (1922-1996). Indische Orthodoxie im 'Zeitalter der Ökumene," in Profile gelebter Theologie im Orient. Sidney Harrison Griffith zum 8o. Geburtstag, ed. Martin Tamcke (Wiesbaden: Harrassowitz, 2018), 222. 
the leading personalities of the official and unofficial dialogue between the Eastern Orthodox and Oriental Orthodox churches.

It can therefore be assumed that the openness of the Ethiopian Orthodox Church to ecumenical dialogue in the 196os and 1970s was determined not only by the political and diplomatic interests of Haylä Ślllase, but also by his obvious concerns for the inter-Christian dialogue. Another essential element was the fact that clerics who were open for dialogue were elected patriarchs of the Ethiopian Orthodox Church, and sought to affirm it as an autocephalous church both in the family of Oriental churches and in the rest of the Christian world. They have made the church turn from one for whom "the relations with other Churches have never been a particular characteristic,"9 as Paul Verghese described it, to one who seeks and supports ecumenical dialogue. ${ }^{10}$ The first steps in this direction were made in Amsterdam in 1948, when the Ethiopian Orthodox Church became a founding member of wCC, and ten years later in Ibadan (Nigeria), when it founded the All Africa Council of Churches together with other churches." In the years that followed, the Ethiopian Orthodox Church increased its contacts, especially with the Eastern Orthodox churches and with the Roman Catholic Church, through delegation exchanges with the Churches of Bulgaria, Greece, Romania, Russia and Yugoslavia, and also through the meeting between Emperor Haylä Śəllase and Pope Paul VI in 1970. ${ }^{12}$

The most substantial relations of this period, however, were maintained with the Eastern churches and impelled by the theological dialogue between

$9 \quad$ Paul Verghese, "Beziehung zu anderen Kirchen und ausländischen Missionen in Äthiopien," in Koptisches Christentum. Die orthodoxen Kirchen Ägyptens und Äthiopiens, ed. Paul Verghese, trans. Ingrid Jonas (Stuttgart: Evangelisches Verlagswerk, 1973), 200.

10 Concerning the ecumenical relations of the Ethiopian Orthodox Church, see: Verghese, "Beziehung," 200-207; Owen Lambert, "Ecumenism in Ethiopia," African Ecclesiastical Review 21 (1979): 172-179; Stéphane Ancel, Giulia Bonacci and Joachim Persoon, "The Ethiopian Orthodox Tewahedo Church and the Eritrean Orthodox Tewahedo Church," in Eastern Christianity and Politics in the Twenty-First Century, ed. Lucian Leustean (New York: Routledge, 2014), 508-511; Ayalkibet Berhanu, "Ecumenical Dialogue in the Ethiopian Orthodox Tewahedo Church," in Orthodox Handbook on Ecumenism. Resources for Theological Education, ed. Pantelis Kalaitzidis et al. (Oxford: Regnum Books, 2014), 564-575; Stanislau Paulau, "Beyond Words. Practical Dialogue between the Ethiopian Orthodox Täwaḩədo Church and the Eastern Orthodox Church Family," in The Dialogue between the Eastern Orthodox and Oriental Orthodox Churches, ed. Christine Chaillot (Volos: Volos Academy Publications, 2016), 415-422.

11 Kai Merten, Das äthiopisch-orthodoxe Christentum. Ein Versuch zu verstehen (Berlin: Lit, 2012), 302-303.

12 Verghese, "Beziehung," 207. 
the two church families ${ }^{13}$ which occasioned several meetings in Addis Abäba. The first part of the present study will deal with these, whereupon I will try to show how the Eastern Orthodox side responded to the theological agreements from Addis Abäba in the second part.

\section{Theological Consultations in Addis Abäba Relevant for the Dialogue between Eastern and Oriental Orthodox Churches}

The first of these theological consultations took place in Addis Abäba from 15 to 21 January 1965 , being convened at a time that was convenient for dialogue in both church families. It should be mentioned that the Chalcedonians were very open towards the Oriental Orthodox churches at the First Pan-Orthodox Conference in Rhodes in $1961,{ }^{14}$ where the Ethiopian Orthodox Church and other Non-Chalcedonian churches had sent their representatives. Moreover, important debates had just taken place between Chalcedonians and NonChalcedonians at the first meeting of the unofficial dialogue, which was held in Aarhus in $1964 .{ }^{15}$ The idea of organizing a theological conference in Addis

13 The dialogue began with four unofficial dialogue sessions organized in Aarhus (1964), Bristol (1967), Geneva (1970) and Addis Abäba (1971). The representatives of the two church families debated about Christology, the lifting of anathemas, and the recognition of saints. The official dialogue started in 1985 with a meeting in Chambésy, where the delegations evaluated the unofficial consultation and discussed the methodology of future meetings. Three other dialogue sessions followed: one in the Egyptian monastery Anba Bishoy (1989), and two in Chambésy (1990, 1993). The delegations adopted two agreed statements which expressed the identity of faith between the two church families. Furthermore, the statements requested the mutual lifting of anathemas and the restoration of the full communion. The two delegations have left the churches to decide when this step will be taken, but so far this has not happened. See Ovidiu Ioan and George Martzelos, "Eastern Orthodox-Oriental Orthodox Dialogue. A Historical and Theological Survey," in Orthodox Handbook on Ecumenism. Resources for Theological Education, ed. Pantelis Kalaitzidis et al. (Oxford: Regnum Books, 2014), 508-535.

14 Regarding the Oriental Orthodox churches, the conference recommended the study of the means for unity, the exchange of students and professors, the organization of theological consultations, as well as the study of history, doctrine, and worship. 13 representatives of the Non-Chalcedonian churches were invited to the conference and participated as observers. See Ioannis Karmiris, "Relations between the Orthodox and the NonChalcedonian churches and the beginning of the preparatory Dialogue between them," Abba Salama 1 (1970): 139 .

15 The meeting took place from 11-15 August 1964 and had as a topic the Christological difference between the Orthodox and the Oriental Orthodox churches. For the papers and minutes of the consultation, see: The Greek Orthodox Theological Review 10, no. 2 (1964): 7-16o. 
Abäba came from the emperor of Ethiopia, Haylä Śəllase, ${ }^{16}$ who declared himself an advocate of the dialogue between Eastern and Oriental Orthodoxy by saying in a press conference that

one of the major desire of my life is to gather at the same table the heads of the Oriental Orthodox Churches, divided from the vigorous branch of Orthodoxy due to the rejection of the Synod of Chalcedon, and also the heads of the Eastern Orthodox Churches, who remained faithful to the next four Ecumenical Synods. ${ }^{17}$

The emperor therefore invited both the heads of the Oriental Orthodox and those of the Eastern Orthodox churches to the conference in Addis Abäba. However, the latter declined the invitation ${ }^{18}$ and planned to send just their representatives, but shortly before they left for the consultation the organizers announced its restriction to the Oriental Orthodox churches only. ${ }^{19}$ One reason for this could be the fact that the non-Chalcedonians wished to be at liberty to discuss their agenda as a communion of churches, as Kenneth F. Yossa noticed. ${ }^{20}$ Another reason could be that the Orientals thought that without the Eastern leaders the conference would no longer have the scope they had originally desired, which is why they restricted it to their own church family. But despite this, the assembly from Addis Abäba went down in history as the first meeting of the heads of the Oriental Orthodox churches at a common theological conference, after 15 centuries. ${ }^{21}$

The consultation started with discussions about internal matters of the Oriental churches such as the attitude towards the challenges of the modern

16 Friedrich Heyer, Die Kirche Äthiopiens. Eine Bestandaufnahme (Berlin: Walter de Gruyter, 1971), 283-284.

17 Marius Florescu, Etapele unui dialog uitat. Spre comuniunea sacramentală deplină dintre Biserica Ortodoxă și Bisericile Ortodoxe Orientale (Timișoara: Astra Museum, 2007), 27 , fn. 25 .

18 Ioannis Karmiris mentioned as a possible reason for this refusal the lack of time for the preparation. See Karmiris, "Relations," 144.

19 Ibid.

20 Kenneth Yossa, Common Heritage, Divided Communion. The Declines and Advances of InterOrthodox Relations from Chalcedon to Chambésy (Piscataway: Gorgias Press, 2009), 101.

21 Heyer, Die Kirche Äthiopiens, 283. The participants were Patriarch Cyril vi of the Coptic Church, Patriarch Ignatius Jacob III of the Syrian Orthodox Church, Catholicos Vasken I of Armenia, Catholicos Koren I of Cilicia, Archbishop Tewoflos of Harar (representing Patriarch Basəlyos of Ethiopia, who was ill), and Catholicos Baselios Augen I of the Malankara Orthodox Syrian Church. Each church also invited 4 5 clerics and theologians. See Karmiris, "Relations," 144-145. 
world, the pastoral care of young people and family, the theological education and church administration. Afterwards, the participants discussed their relations with other churches and at the end issued a statement regarding the Eastern Orthodox Churches, the Roman Catholic Church, and the other member churches of the wCc. ${ }^{22}$ In this statement, they declared that the dialogue with the Eastern Orthodoxy was the first step to be taken by their churches towards Christian unity, given the doctrinal similarities and the spiritual kinship between both families. ${ }^{23}$ Consequently, the conference decided to initiate

a fresh study of the Christological doctrine in its historical setting [...] taking into account the earlier studies on this subject as well as the informal consultations held in connection with the meetings of the World Council of Churches. Meanwhile, we express our agreement that our church could seek closer relationship and cooperate with the Eastern Orthodox Churches in practical affairs. ${ }^{24}$

These decisions stimulated the interest in the dialogue and were very much welcomed by the Eastern Orthodoxy. A positive reaction to this came only a few months later through the Encyclical Letter issued by the Ecumenical Patriarchate on 9 June 1965 , which mentions that the official dialogue between the two church families should start immediately. ${ }^{25}$ Unfortunately, the initiation of an official dialogue was not possible in the years that followed, but the availability for dialogue shown in the middle of the 196os led to three other unofficial consultations held in Bristol (1967), Geneva (1970) and Addis Abäba (1971).

The meeting held in Addis Abäba in 1971 was the fourth and the last unofficial theological consultation between Eastern and Oriental Orthodox churches. ${ }^{26}$ It was convened for 22 to 23 January, taking advantage of a meeting of

22 For the papers and decisions of the conference, see: The Oriental Orthodox Churches. Addis Ababa Conference, January 1965 (Addis Ababa, 1965); "Decisions of the Conference of the Heads of United Orthodox Churches. Addis Ababa, Ethiopia, January 15-21, 1965," The Ecumenical Review 17, no. 2 (1965): 178-189.

23 Ibid., 187.

24 Ibid.

25 Georgios Martzelos, "Der Theologische Dialog der Orthodoxen Katholischen Kirche mit den Nicht-Chalkedonensischen Kirchen des Ostens. Chronik, Auswertung, Perspektiven," in Die Orthodoxe Kirche. Eine Standortbestimmung an der Jahrtausendwende. Festgabe für Prof. Dr. Dr. Anastasios Kallis, ed. Evmenios von Lefka, Athanasios Basdekis and Nikolaus Thon (Frankfurt am Main: Lembeck, 1999), 179.

26 For the papers and minutes of the consultation, see: "Addis Ababa Consultation, January 22 and 23, 1971," The Greek Orthodox Theological Review 16, no. 1-2 (1971): 211-259. 
the Central Committee of the WCC organized at that time in the Ethiopian capital. ${ }^{27}$ This meeting gathered many of the theologians who were already involved in the dialogue between the two Orthodox churches, which made it easier to establish a study group in order to continue the unofficial theological discussions started in Aarhus, Bristol and Geneva. Furthermore, the idea of such a meeting was very much supported by Emperor Haylä Ślllase and by the acting Ethiopian Patriarch Tewoflos, who have provided suitable conditions for it. $^{28}$ There are a few details worth mentioning: the fourth unofficial consultation was the shortest unofficial dialog meeting, the first on the territory of an Oriental Orthodox Church, the only one in a country whose population was mostly Oriental Orthodox, and the only big meeting outside Europe. ${ }^{29}$

The consultation was presided over by the Greek Professor Nikos Nissiotis and by the Indian Fr. Paul Verghese, who announced from the beginning that it was not going to be like the previous three meetings, because of its late convocation. Accordingly, just two papers were presented at this meeting, which addressed the question of lifting the anathemas and the recognition of saints, as requested by the organizers. ${ }^{30}$ The first paper was that of Fr. Vilakuvelil C. Samuel, entitled Condemnation of Teachers and Acclamation of Saints in the Eastern and Oriental Orthodox Churches, while the second was read by Fr. Vitaly Borovoy with the title Recognition of Saints and the Problems of Anathemas. A Summary of the Views of N. Berdyaev, S. Bulgakov and A.V.Kartashev. The two papers were then discussed by 30 theologians who attended the consultation, whereupon they wrote the summary of their conclusions. As was likely to be expected, the Ethiopian Orthodox delegation to this event was the most numerous, comprising nine members. ${ }^{31}$ They made important contributions especially during the first and third dialogue sessions (of five in total), showing willingness and enthusiasm and raising essential questions about the issue of lifting anathemas. ${ }^{32}$

After presenting and discussing the papers, the members of both traditions agreed that in order to reach a union, the lifting of anathemas was an essential step, which required the unity in faith. But the lifting of anathemas against certain persons who were regarded as saints by the other tradition, should

\footnotetext{
$27 \quad$ For some literature about it, see fn. 1.

28 “Addis Ababa Consultation," 215, 234.

29 Ibid., 215; Yossa, Common Heritage, 106.

$30 \quad$ "Addis Ababa Consultation," 215-216.

31 For the list of participants, see: ibid., 214.

32 I have in mind especially the questions raised by Mikrä Śllase Gäbrä Amanu'el and Abäbaw Yəggəzaw. For the minutes of the consultation, see fn. 26.
} 
not imply their recognition as saints in the church where they were previously anathematized. As an argument, the participants referred to the fact that autocephalous churches did not have identical liturgical calendars and lists of saints. For them, it was very clear that the church had the authority to lift anathemas when needed, this being an act which is not to be done exclusively by an Ecumenical Synod, and which does not compromise the infallibility of the church. The study group also agreed that the lifting of anathemas is a process that should be prepared by the churches through study of the teachings of the anathematized ones, of the circumstances under which they were anathematized, as well as of the ways in which the churches lifted anathemas in the past. Many of the participants considered that the churches should not lift anathemas formally, in a ceremony, but rather drop them quietly and announce at the time of union that the anathemas had been lifted. The consultation also recommended the elimination of the condemnations from the liturgical texts and hymns and the actualization of the theological manuals and catechetical materials. Finally, it was agreed that a deeper study of the question What is a saint was needed, and both sides expressed the hope that the work done at the four informal consultations would be continued by the churches through an official dialogue. ${ }^{33}$

A few months after the unofficial theological consultation between Orthodox and Oriental Orthodox churches in Addis Abäba, the Ethiopian capital was again the main location of discussions concerning the dialogue of the two church families. From 18 to 28 August 1971, the Inter-Orthodox Theological Commission for the Dialogue with the Non-Chalcedonian churches gathered there for the first time since its formation. ${ }^{34}$ This commission was appointed by the Fourth Pan-Orthodox Conference (Chambésy, 1968) in order to prepare the dialogue with the Oriental churches by drawing up lists of the questions which needed to be answered on the way to unity. ${ }^{35}$ The meeting was convened with the consent of the Eastern Orthodox autocephalous churches by the Ecumeni-

33 "Addis Ababa Consultation," 211-213.

34 At the beginning, the meeting was set by the Holy Synod of the Ecumenical Patriarchate for the first ten days of January 1971 in Alexandria, but after some months the location was moved to Addis Abäba. Finally, another change occurred and the date of the meeting was moved from January to August 1971. See "Contacts des orthodoxes avec les Églises non-chalcédoniennes," Episkepsis 12, no. 1 (1970): 5; "La première rencontre de la Commission interorthodoxe de dialogue avec les non-chalcédonniens à Addis-Abeba," Episkepsis 19, no. 1 (1970): 4; “La question ecclésiologique au coeur du probleme de l' union des Églises non-chalcédoniennes avec l'Église Orthodoxe," Episkepsis 36, no. 2 (1971): 3.

35 Damaskinos, Metropolitan of Switzerland, "The Theological Dialogue between the Orthodox and the Oriental Orthodox Churches," in Towards Unity. The Theological Dialogue 
cal Patriarch Athenagoras, who chose Addis Abäba as a location based on the availability shown once again by Emperor Hुaylä Śəllase and Patriarch Tewoflos of Ethiopia. ${ }^{36}$

The consultation was attended by 17 members ${ }^{37}$ and led by the Metropolitan Chrysostomos of Myra as president and by the Metropolitan Methodios of Aksum as secretary. In the opening session, the participants listened to the message of the emperor read by the Minister of the Imperial Court, and to the message of the Ethiopian patriarch, who attended the meeting during the opening day. Afterwards, short messages sent by all other heads of the Oriental Orthodox churches, ${ }^{38}$ except the patriarch of the Coptic Church, ${ }^{39}$ were read as well as words of welcome of the Orthodox churches represented at the conference. ${ }^{40}$ The opening session ended with the paper of Metropolitan Methodios about the aspects on which the union of the two church families depends. ${ }^{41}$ During the next dialogue sessions three other papers were analyzed and discussed, one written by Professor Ioannis Karmiris about the Christology of the two churches, another by Fr. Dumitru Stăniloae concerning Christological issues and the lifting of anathemas, and the last one by the Romanian Bishop

between the Orthodox Church and the Oriental Orthodox Churches, ed. Christine Chaillot and Alexander Belopopsky (Geneva: Inter-Orthodox Dialogue, 1998), 31.

36 Dumitru Stăniloae, "Perspectivele dialogului cu Bisericile Vechi Orientale. Lucrările comisiei interortodoxe de la Addis Abeba," Biserica Ortodoxă Română 89, no. 9-10 (1971): 978.

37 For the list of participants, see: Panayitis Fouyas, "The First Meeting of the Inter-Orthodox Theological Commission for the Dialogue with the Ancient Oriental Churches," Ekklesiastikos Pharos 53 (1971): 685; Methodios, Metropolitan of Aksum, "The Dialogue between the Orthodox and Oriental Churches. The Conference of the Inter-Orthodox Theological Commission held in Addis Ababa from 18 to 28 August 1971," Abba Salama 4 (1973): 12. The metropolitan reports that not all the autocephalous churches were represented there. The delegates of the Churches of Antioch, Serbia, Bulgaria, and Czechoslovakia were absent, while the Church of Poland was represented by a bishop of the Patriarchate of Moscow.

38 For the messages of the emperor and of the heads of the Oriental Orthodox Churches, see: Fouyas, "The First Meeting," 686; Methodios, "The Dialogue," 13-15; Stăniloae, "Perspectivele dialogului," 979-980.

39 The Metropolitan Methodios tried to find the reason for which the Coptic Church did not send a welcome message to this consultation. He supposed that "the reasons for their silence should not be attributed to any reactionary policy of this Church to the problem of Eastern Church unity, although we must not forget, that the Coptic Church is reluctant to enter into full unity with the Orthodox Churches. She gives too much nationalistic spirit to her independence from the Greek Church." See Methodios, "The Dialogue," 13-14.

40 Stăniloae, "Perspectivele dialogului," 980.

41 For this paper, see: Methodios, Metropolitan of Aksum, "Inter-Orthodox Theological Commission for the Dialogue with the Non-Chalcedonian Churches. Addis Ababa, 18-29 August 1971. A Statement by Metropolitan Methodios of Aksum, representative of the Patriarchate of Alexandria," Abba Salama 3 (1972): 132-139. 
Antim of Târgoviște about the recognition of the four later Ecumenical Councils by the non-Chalcedonians. ${ }^{42}$

After ten sessions of deliberation, the Inter-Orthodox Commission summarized the conclusions in 14 points. ${ }^{43}$ They announced that the preparation that had been done until that moment was sufficient and the two church families could advance to an official dialogue. ${ }^{44}$ This dialogue should re-examine and evaluate the Christology of both traditions, as well as the question of lifting anathemas and recognition of the Ecumenical Councils. As an addition, the commission proposed that the union of the churches should not imply any absorption of one church by the other in cases where they shared territories. Finally, it was suggested to the Oriental Orthodox churches to arrange the appointment of a commission similar to the Inter-Orthodox one, in order to evaluate the achievements of the dialogue. Besides this, the nomination of a sub-committee with three members was also recommended, which should meet with the sub-committee of the Inter-Orthodox Commission to define the agenda for the first joint meeting of the theological commissions of the two church families.

The non-Chalcedonians accepted the suggestions of the Inter-Orthodox Commission, and convened the Permanent Committee of their churches ${ }^{45}$ which appointed the members of the sub-committee. Hence, in 1973, the two sub-committees gathered in Athens for the first time, starting to set up a pro-

42 A summary of these papers in English can be found in the article of the Metropolitan Methodios. See Methodios, "The Dialogue," 23-30. For the complete papers of the Romanian delegation, see: Stăniloae, "Perspectivele dialogului," 982-988.

43 For the decisions of the inter-orthodox commission, see: Methodios, "The Dialogue," 3133; Stăniloae, "Perspectivele dialogului," 989-991. A summary of the conclusions in French was published in one number of Episkepsis. See "Communique de la Commission théologique interorthodoxe pour le dialogue avec les Églises Orientales Anciennes, AddisAbéba, 18-28 août 1971," Episkepsis 38, no. 2 (1971): 9-10.

44 After Fr. Stăniloae's paper, the participants discussed the validity of the results of the unofficial dialogue meetings. While Ioannis Karmiris considered it appropriate that the Inter-Orthodox Commission confirm these resolutions, others requested that the Commission at least take them into account. The Metropolitan Methodios of Aksum and Ioannis Romanidis disagreed. The former thought the organizers of the four unofficial consultations "overestimated the results of these meetings and they hastened to issue their resolutions, without corresponding them with what the participants represented in their deliberations and with the reality that existed in the Churches in both sides." For I. Romanidis, the resolutions of the unofficial dialogue are not to be regarded as a basis for the official dialogue "because actually they have not reached any Christological agreement." For their opinions, see: Methodios, "The Dialogue," 26-27. 
gram for the joint commission; ${ }^{46}$ this work continued two years later at a meeting in Addis Abäba from 9 to 13 January $1975 .{ }^{47}$ It was the last theological consultation of the two church families in the Ethiopian capital.

It is very surprising that the Ethiopian Orthodox Church was able to organize this event, given the fact that Ethiopia was going through the Marxist Revolution of the Derg, which started in 1974. It resulted in an unprecedented situation for the Ethiopian Orthodox Church, because it lost state support through the draft constitution of the new regime, which came into effect in August 1974 and proclaimed the separation between church and state. ${ }^{48}$ Emperor Haylä Śəllase, who always encouraged the organization of ecumenical meetings in Addis Abäba, was removed from office in September 1974, and one day before this incident Patriarch Tewoflos acknowledged the revolution. ${ }^{49}$ The new regime was aware of the significant influence the Ethiopian Orthodox Church had in society and tried to control and use the church for its own political interests, despite the proclaimed secularity. For instance, the Derg continuously supported the External Relations Department of the Ethiopian Orthodox Church, ensuring that it would defend its actions and policies at an international level during inter-religious conferences and exchanges of ecclesiastical delegations. ${ }^{50}$ It was probably for these reasons that the church was allowed to hold the second dialogue meeting of the sub-committees of Eastern and Oriental Orthodox Churches in Addis Abäba in early 1975.

The sub-committees decided that "the time is ripe and the preparatory work has been completed for the Conference of the two Theological Commissions." ${ }^{1}$ Consequently, the agenda of the forthcoming conference was finished, and it was agreed that it should be convened in July 1976, even though a host church had not yet been established. As a precondition for choosing the venue it was specified that the place should have a comprehensive library, for consultation should it be needed. ${ }^{52}$ Regarding the topics to be discussed, the members chose the Christology of John of Damascus, the Christology of Severus of Antioch,

46 Yossa, Common Heritage, 107-108.

47 'Dialogue entre l'Église orthodoxe et les anciennes Églises orientales: réunion des souscommissions," Proche-Orient Chrétien 25, no. 1 (1975): 100.

48 Haile Mariam Larebo, "The Ethiopian Orthodox Church and Politics in the Twentieth Century: Part II," Northeast African Studies 10, no. 1 (1988): 14.

49 Ancel and Ficquet, "The Ethiopian Orthodox Tewahedo Church," 77.

50 Haile Mariam Larebo, "The Ethiopian Orthodox Church," 17.

51 Methodios, Metropolitan of Aksum, "The Second Meeting of the Sub-Committees for the Theological Dialogue between Eastern and Oriental Orthodox Churches," Abba Salama 7 (1976): 239 .

"Dialogue entre l'Église orthodoxe," 100. 
and issues related to the Ecumenical Councils. For each of these topics the sub-committee asked certain theologians of both church families to prepare and present papers at the Conference. They were commissioned to send the final form of these papers to Metropolitan Methodios of Aksum by the end of December $1975 .{ }^{53}$ Finally, the participants decided to communicate the results of the joint sub-committee meetings to the heads of the Eastern and Oriental Orthodox churches for analysis. ${ }^{54}$

But although the sub-committees were very enthusiastic during the assembly in Addis Abäba, and despite the thorough preparation of the first official dialogue meeting, it was not realized in 1976 . The two church families had to wait no less than a decade until they gathered for the first time for an official dialogue (1985, Chambésy/Geneva).

\section{3 \\ The Reaction of the Eastern Orthodox Theology to the Agreements from Addis Abäba}

Among all the meetings between the two church families organized in Addis Abäba, the one that generated the most interest for the theologians who took part in the dialogue was the 4th unofficial meeting, in January 1971. This is because the Eastern and Oriental Orthodox representatives discussed the issue of lifting anathemas which is of fundamental importance to the unification of the two churches. In the following, I will talk about the way in which the Eastern Orthodox theologians reacted to the theological agreement form January 1971, taking into account, first of all, the period before the official dialogue, afterwards the time of the official dialogue, and, in the end, the years that followed it.

\subsection{Before the Official Dialogue}

The first reaction comes from Fr. D. Stăniloae. ${ }^{55}$ He expressed his view in the talk in front of the Inter-Orthodox Theological Commission in August 1971, which I spoke about already, in which he favoured many aspects from the

\footnotetext{
53 Methodios, "The Second Meeting," 239-240.

54 Yossa, Common Heritage, 110.

55 For Stăniloae's contribution to the dialogue with the Oriental Orthodox churches, see: Ciprian Toroczkai, "Toward an Expanded Formula of the Chalcedon Dogmatic Definition? Fr. Dumitru Staniloae's Contribution to the Dialogue with Non-Chalcedonian Churches," Greek Orthodox Theological Review 59, no. 1-4 (2014): 145-16o.
} 
agreement. ${ }^{56} \mathrm{Fr}$. Stăniloae considered the lifting of anathemas to be an important step for the unity, but conditioned by an identity of faith between the two churches. Apart from the Addis Abäba agreement, he added the necessity for a common Christological definition in order to lift the anathemas. ${ }^{57}$ Further, the Romanian theologian asserts that the official statement of cancelation should be preceded by thorough studies on the reasons that led to anathema. They would have the role of preparing the general atmosphere in the churches so that "each side would get the feeling that it did not act contrary to its Fathers who wrote against the other side." ${ }^{58} \mathrm{Fr}$. Stăniloae supports the agreement of Addis Abäba in suggesting that the churches could gradually abandon the anathemas until they fade into oblivion, given the interim consensus on the identity of faith reached by the two sides during the unofficial dialogue. This could be done by removing the references by which non-Chalcedonians are condemned from the liturgical books and theological handbooks. At the end of his speech, Fr. Stăniloae says that the elimination of the anathemas should not imply that those who were previously anathematized would now be recognized as saints, as this was "a problem that could be left for the spiritual evolution of the future." ${ }^{59}$ The Romanian theologian referred again to the cancelation of anathemas in the debates after the speech. He disagreed with the representative of the Church of Cyprus, who proposed confusingly that only a new Ecumenical Synod could cancel the anathemas of another Synod, and not even that one. Also, he confessed that he was a bit surprised that the anathema on cardinal Humbert and his adepts was cancelled so easily, whereas the anathema on Dioscorus was a more difficult case for some, even after the same faith between the two churches had been established. ${ }^{60}$

56 Stăniloae's paper was entitled "Considerations on the Results of the 4th Unofficial Consultation between Chalcedonian and Non-Chalcedonian Orthodox Theologians held in Addis Ababa (22-23 January 1971)." This topic was recommended by the Orthodox Center of the Ecumenical Patriarchate in Chambésy, Geneva. See Stăniloae, "Perspectivele dialogului," 982. For a summary of this paper in English, see fn. 42. Despite its title, the paper does not exclusively address the issues discussed at the meeting in January 1971. The author begins with the exposition of the opinion of the Romanian hierarchs and theologians regarding the dialogue between the two church families, after which it addresses the Christological issue. The proposals on lifting the anathemas are analyzed only in the last third of the paper.

Stăniloae, "Perspectivele dialogului," 985 .

58 Ibid.

59 Ibid., 986. Cf. Toroczkai, "Toward an Expanded Formula," 155.

6o Stăniloae, "Perspectivele dialogului," 988-989. Cf. Toroczkai, "Toward an Expanded Formula," 155 . 
Metropolitan Chrysostomos of Myra had a more critical approach than Stăniloae. In a paper he presented at a conference organized by the Foundation Pro Oriente, in $1979,{ }^{61}$ he says that both church families show great enthusiasm for the lifting of anathemas. ${ }^{62}$ He appreciates the fact that the two parties tried to reach a joint decision at the 4th unofficial meeting, but suggests that it lacked a more detailed preparation, by saying "it is not exaggerated to affirm that the discussion in Addis Abäba was an ad hoc meeting in fact."63 Furthermore, Metropolitan Chrysostomos analyses paragraph 4 of the agreement, which states the necessity of an identity of faith for the cancelation of the anathemas. Therefore, he asks the following question: is its lifting the very final purpose of the unity, or is it only a step in our way for the dialogue and unity? $\mathrm{He}$ argues that if it were the final purpose, it would not be brought into discussion as long as the dialogue had not been finished. On the other hand, if it were only a step, then it would be a commendable gesture, because it would reflect the wish of the two families for mutual understanding and collaboration, in the same way it happened in the case on anathemas cancelation between Rome and Constantinople. ${ }^{64}$ Between these two choices, the metropolitan seems to favour the latter.

Regarding the paragraphs 5 and 6, which analyse the possibility of lifting anathemas of certain Ecumenical Synods, Metropolitan Chrysostomos is rather reserved. He says that the anathemas were not given only "for pastoral and other reasons,"65 as the participants of the 4th unofficial discussion concluded. He argues that the excommunications of the 4 th and 5 th centuries were based on dogmatic reasons. Therefore, it seems the anathema was indeed the way the church protected the community against spiritual dangers, so it had a pastoral intention, but these anathemas also suggest that a doctrinal error existed at the anathematized ones. For these reasons, the metropolitan finds that the lifting of anathemas for the Oriental Orthodox churches could not be simply solved by oikonomia, as the Addis Abäba agreement stated, and that

61 Metropolitan Chrysostomos was a member of the Holy Synod of the Ecumenical Patriarchate and represented it at the conference organized by Pro Oriente in Vienna on 29th of October 1979. In my research I used the French translation of his paper, which was published in the journal Proche-Orient Chrétien. See Chrysostome, métropolite de Myre, "Le dialogue entre l'Église orthodoxe et les Églises de l' ancien Orient. Appréciacions et perspectives," Proche-Orient Chrétien 30, no. 1-4 (1980): 14-57.

62 Chrysostome, "Le dialogue," 46.

63 Ibid., 48.

64 Ibid., 48-49.

65 Ibid., 49 . 
is why it should be treated by the Eastern Orthodox more carefully. ${ }^{66}$ Lastly, Metropolitan Chrysostomos accepts the suggestions of paragraph 7 on the need for studies concerning the doctrine of the anathematized ones, the circumstances under which they were excommunicated, and the real purpose of their writings, whereupon he agrees with the idea that those from whom the anathema will be raised should not necessarily have to be canonized. ${ }^{67}$

\subsection{During the Official Dialogue}

In the time of the official dialogue, which took place between 1985 and 1993, an Eastern Orthodox reaction regarding the lifting of anathemas and the veneration of saints belonged to Fr. John Meyendorff. In his study Chalcedonians and Non-Chalcedonians: Last Steps to Unity, he says that the clarification of this matter seems to be more difficult than the establishment of the identity of faith, because both church families insist on faithfulness to their own tradition. ${ }^{68}$ Unlike the 11th paragraph of the agreement of Addis Abäba, which stated that the anathemas can be cancelled before establishing a solution to the question of saints' veneration, Fr. Meyendorff insists that the churches, first of all, have to come to an agreement on this matter. He suggests that this agreement should take into account the fact that "the Church never believed in the infallibility of any human being, not even the saints." ${ }^{\prime 69}$ He gives the example of St. John Chrysostom, considered to be a heretic and impostor by the Saints Epiphanius of Salamis and Cyril of Alexandria, and also the example of Bishop Peter the Iberian, an adversary of the Chalcedon venerated by the Church of Georgia. ${ }^{70}$

The official dialogue took into account the matter of lifting anathemas for the first time at the 3 rd official meeting of the Joint Commission for Dialogue, organized in Chambésy from 23rd to 28th September 1990. There, the representatives of the two churches debated over more documents, among which was also the agreement of the 4 th unofficial meeting from Addis Abäba. ${ }^{71}$ They adopted afterwards the Second Agreed Statement. The 1oth paragraph of this text refers to the lifting of anathemas and strongly reflects the proposals from

66 Ibid.

67 Ibid., $5^{\mathrm{O}-51 .}$

68 John Meyendorff, "Chalcedonians and Non-Chalcedonians: The Last Steps to Unity," St. Vladimir's Theological Quarterly 33, no. 4 (1989): 325.

69 Ibid., 326.

70 Ibid., $325-326$.

71 Christine Chaillot and Alexander Belopopsky, ed., Towards Unity. The Theological Dialogue between the Orthodox Church and the Oriental Orthodox Churches (Geneva: Inter-Orthodox Dialogue, 1998), 62. 
Addis Abäba. ${ }^{72}$ Thus, the cancelation of anathemas is considered the ultimate step on the way to unity, and the essential reason for which it can be realized is the conviction that the Fathers and the Synods under the anathema are not heretical. Lastly, the Second Agreed Statement recommends the two church families to lift the anathemas, saying that the way this should be done can be decided by each church on its own. ${ }^{73}$

The Joint Commission for Dialogue developed the methodology for the lifting of anathemas three years later, at the 4th official meeting. It took place in Chambésy, from 1 to 6 November 1993. During the debates, each commission presented a report with proposals for the completion of the agreement of Addis Abäba from 1971 and of the stipulations regarding the cancelation of anathemas from the Second Agreed Statement. One of the suggestions from the Eastern Orthodox theologians was about the solemn concomitant lifting of the anathemas by both Orientals and Easterners reading a document signed by the two sides, to which they could attach some peace letters between the leaders of the churches. In these letters, the Oriental Orthodox side should mention, among other things, that the Eastern Orthodox church is fully orthodox, and they should recognize the Synod of Chalcedon and the Ecumenical Synods that followed. ${ }^{74}$ The Oriental Orthodox were quite critical of this report, and considered some of its proposals unacceptable. For instance, they argued against the solemn lifting of anathemas by reading a document, and in favour of a general lifting without mentioning the names of the persons reintegrated into the church. In addition, they rejected any stipulations in the document that they would recognize the Synods after Ephesus. ${ }^{75}$ But eventually, the representatives of the two churches reached a compromise. They decided that, apart from the agreement of Addis Abäba and the Second Agreed Statement, the procedure of lifting the anathemas would also have to mention that they must be cancelled simultaneously by the leaders of all churches, by signing a document which should include a confession of orthodoxy from both families. ${ }^{76}$

\subsection{After the Official Dialogue}

After the official dialogue, a positive reaction to the results regarding the anathemas came from the Synod of the Romanian Orthodox Church. In a declaration from December 1994, the members of the Holy Synod approved the conclu-

\footnotetext{
72 Cf. Yossa, Common Heritage, 154.

73 Chaillot and Belopopsky, Towards Unity, 64.

74 Yossa, Common Heritage, 156.

75 Ibid., 157-158, fn. 179 .

76 Chaillot and Belopopsky, Towards Unity, 68.
} 
sions of the official meetings and mentioned that the anathemas were given in a period characterized "by division, by the absence of a consensus in the formulation of the confession of the faith, and by the absence of fraternal charity."77 Furthermore, they considered necessary that the Synods of the Eastern churches should reach a consensus regarding the cancelation of anathemas, which should be expressed in a joint statement signed by the church leaders. This text could be read afterwards during a Eucharistic celebration officiated by the Primates of both Eastern and Oriental Orthodox churches. ${ }^{78}$

Soon after, the position of the Romanian Orthodox Church and the results of the discussion referring to the lifting of the anathemas were heavily criticized in a memorandum with eleven accusations, promulgated by the monks of Mount Athos in May $19955^{79}$ This text suggests that the anathemas pronounced by the Ecumenical Synods are of divine inspiration and therefore, the remark by the Synod of the Romanian Church about "the absence of fraternal charity [could be considered] profound blasphemy against the Holy Spirit." 80 The Athonite position received a thorough reply form the orthodox Bishop Alexander (Golitzin), who saw in it a closed ecclesiology of neo-cyprianic inspiration and recommended to the Church of Greece and to the Athonite monks to think more about the nature of the anathemas and about their relationship to the doctrine. ${ }^{81}$

The monastic community of Mount Athos was not the only one who criticized the results of the dialogue. In a letter sent to the Greek-orthodox Patriarch Ignatius of Antioch (1979-2012) ${ }^{82}$ in 1997, Patriarch Diodorus of Jerusalem

77 Ibid., 42.

78 Ibid.

79 "Memorandum of the Sacred Community of Mount Athos Concerning the Dialogue between the Orthodox and Non-Chalcedonian Churches," accessed 24.03.2019. URL: http: //orthodoxinfo.com/ecumenism/mono_athos.aspx. The content of this text does not reveal how many of the Athonite monasteries supported it. Cf. Yossa, Common Heritage, 19o, fn. 51.

8o Alexander (Golitzin) of Toledo, "Anathema! Some Historical Perspectives on the Athonite Statement of May, 1995," St. Nersess Theological Review 3, no. 1-2 (1998): 107.

81 Ibid., $116-117$.

82 The Chalcedonian Patriarch Ignatius IV Hazim of Antioch signed a pastoral protocol with the Syrian Orthodox Patriarch Ignatius Zakka I (1980-2014) in November 1991, as a consequence of the positive results of the official dialogue. In this protocol it is said, among other things, that the believers of one church can attend the liturgy of the other church and receive the Holy Sacraments from its clergy, if no priest of their own church exists in their place. A protocol was also signed by the Greek and the Coptic patriarchs of Alexandria in April 2001, dealing with the sacrament of marriage. Cf. Yossa, Common Heritage, 159-166. 
(1980-200o) declared himself unsatisfied with the proposals regarding the lifting of anathemas made by the official dialogue. He expressed discontent with the fact that the Oriental Orthodox churches were not obliged to recognize all decisions and canons from Chalcedon and from the Ecumenical Synods that followed. ${ }^{83}$

The agreements on the lifting of anathemas were criticized again, in a conference about ecumenism organized in September 2004 at the School of Pastoral Theology at The Aristotelian University in Thessaloniki. ${ }^{84}$ The conference decided that the dialogue between Orientals and Easterners at both the official and the unofficial level, did not represent anything except a compromise regarding the faith, and that it was incompatible with the orthodox doctrine. ${ }^{85}$ Among the criticized aspects, the conference also mentioned the revision of the liturgical texts recommended in the 1oth paragraph of the unofficial meeting in Addis Abäba. This position is, to some degree, in accordance with the position of the Holy Synod of the Church of Greece, which rejected the documents of the Joint Commission for Dialogue in February 1994. ${ }^{86}$

The Russian Orthodox Church had a more moderate position in the reports from 1994 and 1997. Even though it did not recognized the results of the Official Dialogue, it welcomed the initiative to hold a dialogue with the NonChalcedonians and considered that further studies were needed in order to lift the anathemas and reach full communion. ${ }^{87}$ At the opposite side, the Orthodox Churches of Georgia and Bulgaria not only declined the results but rejected the very idea of having a dialogue with the Oriental Orthodox churches. 88

A last important reaction regarding the lifting of anathemas belongs to Fr. John H. Erickson, professor emeritus of the Saint Vladimir Theological Seminary. In response to the question who has the authority of cancelling the anathemas? he said that from a juridical point of view they could be cancelled only by the same authority that gave them, or by an entity with equal authority. Therefore, only an Ecumenical Synod, or a Great and Holy Synod would ful-

83 John Erickson, "Anathema: An Obstacle to Reunion?," St. Nersess Theological Review 3, no. 1-2 (1998): 67-75.

84 The 53 participants of the conference belonged to the Churches of Greece, Bulgaria, Romania, Hungary, Georgia, Canada, Serbia, USA, and Russia. Cf. Yossa, Common Heritage, 193 , fn. 61 .

85 Ibid., 192-194.

86 Marius Florescu, "Recunoașterea acordurilor teologice dintre Biserica Ortodoxă și Bisericile Vechi-Orientale (II)," Altarul Banatului 23, no. 1-3 (2012): 111-112.

87 Cf. ibid., 106-109. For the two statements of the Russian Orthodox Church, see: Chaillot and Belopopsky, Towards Unity, 43-44.

88 Yossa, Common Heritage, 192, fn. 58; Florescu, "Recunoașterea," 112-113. 
fil these requirements, ${ }^{89}$ which is why the proposal from the 4 th paragraph of the agreement of Addis Abäba, where it is stated that the anathemas could be lifted slowly, in a silent way, would not comply with the juridical aspect. As to the infallibility of the ecumenical synods, Fr. Erickson agrees with paragraph 6 from Addis Abäba that the lifting of anathemas does not affect it at all, reasoning that "the infallibility does not imply full and direct divine inspiration for each and every statement made in the course of these councils." 90

\section{$4 \quad$ Conclusion}

One can say that the meetings held in Addis Abäba had a significant role in the dialogue between the Eastern Orthodox and the Oriental Orthodox churches on multiple levels. On the one hand, they stimulated the dialogue by showing availability and interest, as was the case with the meeting of the heads of the Oriental churches in 1965. On the other hand, they brought into question essential theological issues, as happened at the fourth unofficial meeting in January 1971. Finally, they contributed to the creation of necessary structures for the development of the dialogue and to the establishment of its agenda, as was done at the meetings from August 1971 and January 1975. All these achievements would not have been possible without the availability for dialogue shown by the Ethiopian Orthodox Church in that time, which was supported by Emperor Haylä Śllase for both political reasons and sincere concern for the dialogue with the Eastern Orthodox Churches.

Regarding the theological contribution of the meetings in Addis Abäba, I have shown that the most relevant discussions took place at the fourth unofficial dialogue meeting in January 1971. There the two churches approached the questions of lifting anathemas and of the recognition of saints, which has proven to be the most difficult obstacle on the way to unity. The conclusions of this meeting show that, despite the short duration and the scanty preparation, it succeeded in answering the most important questions concerning that topic. The main argument for this is the fact that the conclusions from the unofficial consultation in Addis Abäba provided the basis on which the official dialogue established the methodology for the Inter-Orthodox rapprochement.

As to the attitude of the Eastern Orthodox theologians towards the agreements on the lifting of anathemas, we saw that the majority agreed with them,

89 Erickson, "Anathema," 70.

$90 \quad$ Ibid., 71. 
in spite of some constructive criticism, and some tried to expand them. On the other hand, there were also rejections of the agreements and even of the whole dialogue. Such attitudes have at the basis a closed ecclesiology and blame the Oriental Orthodox churches for the separation. Unfortunately, in the years that followed the last official dialogue meetings, the scepticism towards the dialogue covered a significant part of the Eastern and Oriental Orthodox churches. In the Non-Chalcedonian side, the Ethiopian Orthodox Church surprisingly changed its attitude and proved to be an obstacle to advancing the dialogue. This is evident from a book published by the Ethiopian Orthodox Church in 1996, which was prepared by its bishops and theologians and was endorsed by Patriarch Abunä Pawlos. There it is stated that the Christological Formula of the Chalcedonian Fathers

was not felt to be the same as that of the Oriental Orthodox Churches $[\ldots]$ and since the anathemas have been observed for about 15 oo years by our Holy Fathers as inscribed in our liturgical texts and hymnody, they shall not be lifted [...] To lift the anathemas imposed in the past upon those Chalcedonian Fathers and to accept them as saints would dishonour those Oriental Orthodox Church Fathers who condemned the Chalcedonians. ${ }^{91}$

Such statements totally ignore the results of both the official and unofficial theological dialogue, and contradicts all the efforts for unity made by the Ethiopian Orthodox Church for decades. It is reminiscent of the intransigent and unwilling positions of the monastic community of Mount Athos and of the Orthodox Churches of Georgia and Bulgaria, and shares with them a part of the responsibility for the current stagnation of the discussions regarding the lifting of anathemas.

\section{List of References}

"Addis Ababa Consultation, January 22 and 23, 1971." The Greek Orthodox Theological Review 16, no. 1-2 (1971): 211-259.

Alexander (Golitzin) of Toledo. "Anathema! Some Historical Perspectives on the Athonite Statement of May, 1995." St. Nersess Theological Review 3, no. 1-2 (1998): 103-117.

91 The Ethiopian Orthodox Tewahedo Church, ed., The Ethiopian Orthodox Tewahedo Church. Faith, Order of Worship and Ecumenical Relations, 2nd ed. (Addis Ababa:Tansae Publishing House, 1996), 145 . 
Ancel, Stéphane, and Éloi Ficquet. "The Ethiopian Orthodox Tewahedo Church (EOTC) and the Challenges of Modernity." In Understanding Contemporary Ethiopia. Monarchy, Revolution and the Legacy of Meles Zenawi, edited by Gérard Prunier and Éloi Ficquet, 63-92. London: Hurst, 2015.

Ancel, Stéphane, Giulia Bonacci and Joachim Persoon. "The Ethiopian Orthodox Tewahedo Church and the Eritrean Orthodox Tewahedo Church." In Eastern Christianity and Politics in the Twenty-First Century, edited by Lucian Leustean, $49^{8-520}$. New York: Routledge, 2014.

Ayalkibet Berhanu. "Ecumenical Dialogue in the Ethiopian Orthodox Tewahedo Church." In Orthodox Handbook on Ecumenism. Resources for Theological Education, edited by Pantelis Kalaitzidis et al., 564-575. Oxford: Regnum Books, 2014.

Bairu Tafla. "Basəlyos." In EAe 1 (2003): 495-496.

Chaillot, Christine, and Alexander Belopopsky, ed. Towards Unity. The Theological Dialogue between the Orthodox Church and the Oriental Orthodox Churches. Geneva: Inter-Orthodox Dialogue, 1998.

Chrysostome, métropolite de Myre. "Le dialogue entre l'Église orthodoxe et les Églises del' ancien Orient. Appréciacions et perspectives." Proche-Orient Chrétien 3o, no. 1-4 (1980): 14-57.

"Communique de la Commission théologique interorthodoxe pour le dialogue avec les Églises Orientales Anciennes, Addis-Abéba, 18-28 août 1971." Episkepsis 38, no. 2 (1971): 9-10.

"Contacts des orthodoxes avec les Églises non-chalcédoniennes." Episkepsis 12, no. 1 (1970): 5-7.

Damaskinos, Metropolitan of Switzerland. "The Theological Dialogue between the Orthodox and the Oriental Orthodox Churches." In Towards Unity. The Theological Dialogue between the Orthodox Church and the Oriental Orthodox Churches, edited by Christine Chaillot and Alexander Belopopsky, 30-34. Geneva: Inter-Orthodox Dialogue, 1998.

"Decisions of the Conference of the Heads of United Orthodox Churches. Addis Ababa, Ethiopia, January 15-21, 1965." The Ecumenical Review 17, no. 2 (1965): 178-189.

"Dialogue entre l' Église orthodoxe et les anciennes Églises orientales: réunion des souscommissions." Proche-Orient Chrétien 25, no. 1 (1975): 100.

Dirshaye Menberu. “Tewoflos." In Dictionary of African Christian Biography, edited by Jonathan Bonk et al., accessed 29.01.2019. URL: https://acb.org/stories/ethiopia/ tewoflos2/.

Erickson, John. "Anathema: An Obstacle to Reunion?" St. Nersess Theological Review 3 , no. 1-2 (1998): 67-75.

Florescu, Marius, Etapele unui dialog uitat. Spre comuniunea sacramentală deplină dintre Biserica Ortodoxă și Bisericile Ortodoxe Orientale. Timișoara: Astra Museum, 2007. 
Florescu, Marius. "Recunoașterea acordurilor teologice dintre Biserica Ortodoxă și Bisericile Vechi-Orientale (II).” Altarul Banatului 23, no. 1-3 (2012): 106-120.

Fouyas, Panayitis. "The First Meeting of the Inter-Orthodox Theological Commission for the Dialogue with the Ancient Oriental Churches." Ekklesiastikos Pharos 53 (1971): $685^{-689 .}$

Haile Mariam Larebo. "The Ethiopian Orthodox Church and Politics in the Twentieth Century: Part II." Northeast African Studies 10, no. 1 (1988): 1-23.

Heyer, Friedrich. Die Kirche Äthiopiens. Eine Bestandaufnahme. Berlin: Walter de Gruyter, 1971.

"International Joint Commission for Theological Dialogue between the Catholic Church and the Oriental Orthodox Churches Report, Ninth Meeting, Addis Ababa, Ethiopia, January 17 to 21, 2012." Pontifical Council for Promoting Christian Unity, accessed 12.05.2021. URL: http://www.christianunity.va/content/unitacristiani/en/ dialoghi/sezione-orientale/chiese-ortodosse-orientali/commissione-mista-interna zionale-per-il-dialogo-teologico-tra-la/rapporti/testo-in-inglese5.html.

Ioan, Ovidiu, and George Martzelos. "Eastern Orthodox-Oriental Orthodox Dialogue. A Historical and Theological Survey." In Orthodox Handbook on Ecumenism. Resources for Theological Education, ed. Pantelis Kalaitzidis et al., 508-535. Oxford: Regnum Books, 2014.

Karmiris, Ioannis. "Relations between the Orthodox and the non-Chalcedonian Churches and the beginning of the preparatory Dialogue between them." Abba Salama 1 (1970): 138-153.

"La première rencontre de la Commission interorthodoxe de dialogue avec les nonchalcédonniens à Addis-Abeba." Episkepsis 19, no. 1 (1970): 4-5.

"La question ecclésiologique au coeur du probleme de l'union des Églises non-chalcédo niennes avec l'Église Orthodoxe." Episkepsis 36, no. 2 (1971): 3-4.

Lambert, Owen. "Ecumenism in Ethiopia." African Ecclesiastical Review 21 (1979): 172179 .

Lanne, Emmanuel. "Le Comité central du Conseil oecuménique, Addis-Abéba, 10-21 janvier 1971." Irénikon 44, no. 1 (1971): 39-54.

"Les étudiants orthodoxes à l'Assemblée Générale de la F.U.A.C.E. à Addis-Abeba." Episkepsis 71, no. 4 (1973): 8-11.

Martzelos, Georgios. "Der Theologische Dialog der Orthodoxen Katholischen Kirche mit den Nicht-Chalkedonensischen Kirchen des Ostens. Chronik, Auswertung, Perspektiven." In Die Orthodoxe Kirche. Eine Standortbestimmung an der Jahrtausendwende. Festgabe für Prof. Dr. Dr. Anastasios Kallis, edited by Evmenios von Lefka, Athanasios Basdekis and Nikolaus Thon, 177-198. Frankfurt am Main: Lembeck, 1999 .

"Memorandum of the Sacred Community of Mount Athos Concerning the Dialogue between the Orthodox and Non-Chalcedonian Churches," accessed 24.03.2019. URL: http://orthodoxinfo.com/ecumenism/mono_athos.aspx. 
Mersha Alehegne. “Tewoflos." In EAe 4 (2010): 938-939.

Merten, Kai. Das äthiopisch-orthodoxe Christentum. Ein Versuch zuverstehen. Berlin: Lit, 2012.

Methodios, Metropolitan of Aksum. "Inter-Orthodox Theological Commission for the Dialogue with the Non-Chalcedonian Churches. Addis Ababa, 18-29 August 1971. A Statement by Metropolitan Methodios of Aksum, representative of the Patriarchate of Alexandria." Abba Salama 3 (1972): 132-139.

Methodios, Metropolitan of Aksum, "The Dialogue between the Orthodox and Oriental Churches. The Conference of the Inter-Orthodox Theological Commission held in Addis Ababa from 18 to 28 August 1971." Abba Salama 4 (1973): 11-35.

Methodios, Metropolitan of Aksum. "The Second Meeting of the Sub-Committees for the Theological Dialogue between Eastern and Oriental Orthodox Churches." Abba Salama 7 (1976): 239-240.

Meyendorff, John. "Chalcedonians and Non-Chalcedonians: The Last Steps to Unity." St. Vladimir's Theological Quarterly 33, no. 4 (1989): 319-329.

"Papers and minutes of the theological consultation between Eastern and Oriental Orthodox Churches in 1964." The Greek Orthodox Theological Review 10, no. 2 (1964): 7-16o.

Paulau, Stanislau. "Beyond Words. Practical Dialogue between the Ethiopian Orthodox Täwaḩədo Church and the Eastern Orthodox Church Family." In The Dialogue between the Eastern Orthodox and Oriental Orthodox Churches, edited by Christine Chaillot, 415-422. Volos: Volos Academy Publications, 2016.

Pieper, Lukas. "Paulos Mar Gregorios (1922-1996). Indische Orthodoxie im 'Zeitalter der Ökumene'." In Profile gelebter Theologie im Orient. Sidney Harrison Griffith zum 8o. Geburtstag, edited by Martin Tamcke, 219-231. Wiesbaden: Harrassowitz, 2018.

Pinggéra, Karl. "Die Äthiopisch-Orthodoxe Kirche und die Eritreisch-Orthodoxe Kirche." In Die altorientalischen Kirchen. Glaube und Geschichte, edited by Christian Lange and Karl Pinggéra, 41-50. Darmstadt: Wissenschaftliche Buchgesellschaft, 2010.

Stăniloae, Dumitru. "Perspectivele dialogului cu Bisericile Vechi Orientale. Lucrările comisiei interortodoxe de la Addis Abeba." Biserica Ortodoxă Română 89, no. 9-10 (1971): 978-991.

The Ethiopian Orthodox Tewahedo Church, ed. The Ethiopian Orthodox Tewahedo Church. Faith, Order of Worship and Ecumenical Relations. 2nd ed. Addis Ababa: Tansae Publishing House, 1996.

The Oriental Orthodox Churches. Addis Ababa Conference, January 1965. Addis Ababa, 1965 .

Thomas, M.M. "Report of the Executive Committee by the Chairman." The Ecumenical Review 23, no. 2 (1971): 89-104. 
Toroczkai, Ciprian. "Toward an Expanded Formula of the Chalcedon Dogmatic Definition? Fr. Dumitru Staniloae's Contribution to the Dialogue with Non-Chalcedonian Churches." Greek Orthodox Theological Review 59, no. 1-4 (2014): 145-16o.

Verghese, Paul. "Beziehung zu anderen Kirchen und ausländischen Missionen in Äthiopien." In Koptisches Christentum. Die orthodoxen Kirchen Ägyptens und Äthiopiens, edited by Paul Verghese, translated by Ingrid Jonas, 200-207. Stuttgart: Evangelisches Verlagswerk, 1973 .

Yossa, Kenneth. Common Heritage, Divided Communion. The Declines and Advances of Inter-Orthodox Relations from Chalcedon to Chambésy. Piscataway: Gorgias Press, 2009. 